\title{
Impact of Dietary Diversification on the Prognostic Inflammatory and Nutritional Index in School-Age Children in the Nawa Region (Côte d'Ivoire)
}

\author{
Allico Mousso Jean Maurel ${ }^{1,2}$, Agbo Adouko Edith $^{3,4,}{ }^{*}$, Séri Kipré Laurent ${ }^{1,2}$, Boyvin Lydie ${ }^{1,2}$, \\ Kouamé Christophe ${ }^{4}$, Yapi Houphouët Félix ${ }^{1}$ and Djaman Allico Joseph ${ }^{1,2}$ \\ ${ }^{1}$ Biology and Health Laboratory, Félix Houphouët-Boigny University, 01 BP V34 Abidjan 01, Côte d'Ivoire \\ ${ }^{2}$ Department of Medical and Fundamental Biochemistry, Institut Pasteur of Côte d'Ivoire (IPCI), 01 BP 490, \\ Abidjan 01, Côte d'Ivoire \\ ${ }^{3}$ Food Science and Technology Department, Nangui Abrogoua University, 02 BP 801 Abidjan 02, Côte \\ d'Ivoire \\ ${ }^{4}$ International Center for Research Agroforestry (ICRAF), Abidjan, 08 BP 2823 Abidjan 08, Côte d'Ivoire
}

\begin{abstract}
The objective of this work was to study the impact of food diversification based on sweet potato, soybean, and cowpea on the prognostic inflammatory and nutritional index (PINI) in school-aged children in the Nawa region. This study took place from October 2017 to May 2018 among 240 pupils aged 6 to 12, divided into four groups of 60. Four types of meals were proposed: rice with tomato soup and fish (group 1), sweet potato porridge enriched with green soybeans (group 2), sweet potato porridge enriched with white cowpea (group 3), or sweet potato porridge accompanied by white cowpea with green soybeans (group 4). There were three blood samples: before eating meals (phase 0 ), the end of the first trimester (phase 1), and the end of the second trimester (phase 2). Blood assay for C-reactive protein (CRP), orosomucoid, albumin, and prealbumin was performed using COBAS c311 analyzer. PINI was calculated. Groups 3 and 4 showed a slight increase in albumin values $(42.24 \pm 0.95 \mathrm{~g} / \mathrm{L}$ and $41.51 \pm 1.71 \mathrm{~g} / \mathrm{L}$, respectively) compared to group 1. CRP decreased from phase 1 for group $1(2.06 \pm 0.26 \mathrm{mg} / \mathrm{L})$ and group $4(2.38 \pm 0.36 \mathrm{mg} / \mathrm{L})$. Orosomucoid increased insignificantly $(p>0.05)$ in group $3(0.74 \pm 0.04 \mathrm{~g} / \mathrm{L})$ and group $4(0.71 \pm 0.04 \mathrm{~g} / \mathrm{L})$. PINI was reduced by 0.37 (group 1), 0.36 (group 2), 0.46 (group 3) and 0.44 (group 4). Food diversification based on sweet potato and white cowpea has a positive impact on PINI in more than $80 \%$ of pupils.
\end{abstract}

Keywords: Côte d'Ivoire, cowpea, sweet potato, inflammatory and nutritional proteins, soybeans.

\section{INTRODUCTION}

In Côte d'Ivoire, malnutrition is one of the public health problems. In fact, in 2010, the prevalence of malnutrition among school children was $18.36 \%$ in the Nawa region [1]. It has an impact on children's ability to learn and succeed [2]. In order to combat this situation, Agbo et al. [3] suggested dietary diversification for school-age children. According to the US Department of Agriculture and the US Center of Nutrition (1992), dietary diversification means "eat a variety of foods", on the premise that consuming a wide variety of foods will ensure an adequate intake of essential nutrients and, in turn, will lead to a better-quality diet and optimal health outcomes. In addition, the 2015-2020 US Dietary Guidelines recommend choosing a variety of nutrientdense foods across all food groups and within all food groups, with particular emphasis on variety in vegetables and protein sources [4]. For the nutritional management of malnutrition based on the optimal use of locally available nutrient-rich foods to improve the

*Address correspondence to this author at Food Science and Technology Department, Nangui Abrogoua University, 02 BP 801 Abidjan 02, Côte d'Ivoire; Tel: (225) 07077903 64; Fax: (225) 2722442108 ;

E-mail: edipagbo@gmail.com nutritional status of children and prevent malnutrition [5], Agbo et al. [3] focused on nutrient-rich foods such as sweet potatoes, soybeans, and cowpeas. Indeed, the sweet potato (Ipomoea batatas Lam.) is energetic and is rich in vitamins and minerals (mainly potassium), dietary fiber, and proteins [6]. As for soybean (Glycine max), it is classified in the oil-protein category thanks to the richness of its seeds in macronutrients (proteins, lipids, and carbohydrates), micronutrients (minerals, vitamins), and secondary metabolites [7]. In addition, cowpea (Vigna unguiculata L. Walp.) represents an important source of protein for some populations [8].

Malnutrition causes a decrease in nutritional protein while it elevates inflammatory proteins [9]. Since the plasma concentrations of so-called nutritional proteins are influenced by inflammatory syndrome, Ingenbleek and Carpentier [10] proposed to correct the fluctuations of these proteins by variations in more specific proteins of an inflammatory syndrome such as C-reactive protein (CRP) and orosomucoid. In 1985, they proposed an index, called the prognostic inflammatory and nutritional index (PINI), which combines the measurement of two inflammatory proteins (CRP and orosomucoid) and two nutritional-based proteins 
(albumin and prealbumin). However, most studies have assessed malnutrition against anthropometric indices (weight loss, body mass index, measurement of brachial or calf circumference). These measurements are certainly specific to the compartments measured, but they are also not very sensitive [11]. However, in children aged over 5 years, the pathologies have a rather insidious installation and evolution [12]. Thus, the determination of PINI in children is necessary because it could better guide the management of malnutrition.

The objective of this work was to study the impact of food diversification based on sweet potato, soya, and cowpea on PINI in school children in Côte d'Ivoire.

\section{MATERIAL AND METHODS}

\subsection{Study Population}

This research was a longitudinal study conducted over one school year (9 months). It was carried out in four zones (Buyo, Gueyo, Meagui, Soubré) of the Nawa region where the "Vision for change" project set up a cocoa rehabilitation program integrating assessment of the nutritional status of school children visiting school canteens.

The children who participated in this study were between 6 and 12 years old, and consent was obtained from the parents. In addition, the children's general health was certified by a health worker (nurse) during a clinical and laboratory examination before the study took place. Pupils whose age was less than 6 years or over 12 years were not considered in this study.

\subsection{Determination of the Sample Size}

The sample size was calculated using the Leslie Fischer formula below, considering the prevalence of chronic malnutrition in this area [1].

$$
\begin{gathered}
n=\frac{Z^{2} p(1-p)}{i^{2}} \\
n=\frac{(1.96)^{2} \times 0.1836(1-0.1836)}{(0.05)^{2}}
\end{gathered}
$$

$\mathrm{n}$ : minimum sample size for obtaining significant results at a fixed risk level $Z$.

Z: confidence level (the typical value for the $95 \%$ confidence level is 1.96). $\mathrm{p}$ : proportion of children suffering from chronic malnutrition, estimated at $18.36 \%$ in the area according to N'go et al. [1].

Considering a $10 \%$ margin of error, the range of the sample size is (207-253). The study, therefore, considered 240 pupils at a rate of 60 pupils per locality.

\subsection{Sampling}

A standardized questionnaire survey on the sociodemographic data of 240 students from schools in these different localities was carried out.

In addition, blood samples were taken from the students at different times or stages (phases) of the study:

Phase 0: phase before food consumption;

Phase 1: phase after 3 months or one-quarter of the experiment;

Phase 2: phase after 6 months of the experiment.

\subsection{Preparation of Dishes}

Over a school calendar year, the students ate different dishes made with rice, sweet potatoes, soybeans, and cowpeas in school canteens. The dishes were prepared according to the following methods:

\subsubsection{Rice with Tomato Soup and Fish}

Five kilograms of rice were prepared for 30 mins in a cooking pot containing tap water, oil, and onion. After sautéing the onions, garlic, and tomato stew in a little oil, the fish was stirred in with water. The whole thing was left to simmer for 30 to 40 mins, adding cooking salt, pepper, and nutmeg.

\subsubsection{Sweet Potato Porridge Enriched with Green Soybeans}

The sweet potato porridge enriched with green soybeans was made by soaking $1 \mathrm{~kg}$ of green soybeans soaked in hot water, then cooking them for 30 mins in water with a little salt. Ten kilograms of sweet potato were peeled and cut up. After mixing the onions and garlic in a little oil, the tomato paste, precooked soybeans, and water were added. The whole thing was simmered for 20 mins; then, the sweet potato was incorporated. After salting and seasoning with pepper and nutmeg, the whole thing was left to cook for another 30 mins. 


\subsubsection{Sweet Potato Porridge Enriched with White Cowpeas}

The sweet potato porridge enriched with white cowpea was prepared by soaking $1 \mathrm{~kg}$ of white cowpeas in hot water, then cooking them for 45 mins in water with a little salt. Ten kilograms of sweet potato were peeled and cut up. After mixing the onions and garlic in a little oil, the tomato stew, precooked cowpeas, and water were added. The whole was simmered for 20 mins, and then the sweet potato was incorporated. After salting and seasoning with pepper and nutmeg, the whole thing was left to cook for another 30 mins.

\subsubsection{Sweet Potato Porridge Enriched with Green Soybeans and White Cowpeas}

One kilogram of green soybeans was soaked in hot water, then cooked for 30 mins in water with a little salt. One kilogram of white cowpeas was soaked in hot water, skinned, and then soaked for 45 mins in water with a little salt. Ten kilograms of sweet potato were peeled and cut up. After mixing the onions and garlic in a little oil, the precooked tomato stew, cowpeas and soybeans were added. The whole thing was simmered for 20 to 30 mins, and then the sweet potato was stirred in. After salting and seasoning with pepper and nutmeg, the whole thing was left to cook for another 30 mins.

\subsection{Distribution of Dishes}

The different menus were taken as lunch in the school canteen two days a week (Monday and Thursday) during the study. Each child received approximately 300 to $500 \mathrm{~g}$ of food. In the study, each group consisted of students from different schools. Each group received the same meal, distributed as follows:

- Group 1 (control group): rice with tomato stew and fish (RSP). These are the dishes usually served in canteens;

- Group 2: sweet potato porridge enriched with green soybeans (PDS);

- Group 3: sweet potato porridge enriched with white cowpeas (PDN);

- Group 4: sweet potato porridge enriched with green soybeans and white cowpeas (PDSN).

\subsection{Assay of Biochemical Parameters}

The assay of the biochemical parameters was carried out using a COBAS c311 analyzer.

\subsubsection{C-Reactive Protein}

The concentration of CRP was determined by immunoturbidimetry with latex particles sensitized by specific antibodies [13]. This is because CRP reacts in an agglutination reaction with latex particles coated with monoclonal anti-CRP antibodies. The precipitate obtained is measured by turbidimetry at $552 \mathrm{~nm}$ [14].

The assay was carried out with a COBAS c311 analyzer using $2 \mu \mathrm{L}$ of serum to which was added $82 \mu \mathrm{L}$ of R14 solution associated with $48 \mu \mathrm{L}$ of diluent $\left(\mathrm{H}_{2} \mathrm{O}\right)$, then $28 \mu \mathrm{L}$ of R15 solution combined with $14 \mu \mathrm{L}$ of diluent $\left(\mathrm{H}_{2} \mathrm{O}\right)$. The result was obtained 10 mins later.

\subsubsection{Orosomucoid}

Orosomucoidor $\alpha$-1-acid glycoprotein constitutes a marker of the inflammatory reaction. It was assayed by immunoturbidimetry [15], using $2 \mu \mathrm{L}$ of serum to which was added $35 \mu \mathrm{L}$ of $\mathrm{R} 16$ solution combined with $17 \mu \mathrm{L}$ of diluent $\left(\mathrm{H}_{2} \mathrm{O}\right)$.

\subsubsection{Albumin}

Albumin concentrations were determined using a modified bromocresol green binding assay [16]. Albumin at $\mathrm{pH} 4.3$ is sufficiently cationic to combine with bromocresol green (BCG) and form a blue-greencolored complex [17]. The intensity of the blue-green color is directly proportional to the concentration of albumin in the sample. It is measured by the increase in absorbance at $629 \mathrm{~nm}$.

The albumin assay was carried out using a COBAS c311 analyzer using $2 \mu \mathrm{L}$ of serum, to which was added $100 \mu \mathrm{L}$ of R4 solution (mono-reagent) and $20 \mu \mathrm{L}$ of diluent $\left(\mathrm{H}_{2} \mathrm{O}\right)$. The result was obtained 10 mins later.

\subsubsection{Prealbumin}

Prealbumin forms a precipitate in the presence of a specific antiserum; this precipitate can be assayed by immunoturbidimetry at $340 \mathrm{~nm}$ [18].

The prealbumin assay using a COBAS c311 analyzer uses $2 \mu \mathrm{L}$ of the serum to which has been added $100 \mu \mathrm{L}$ of R4 solution (mono-reagent) and $20 \mu \mathrm{L}$ of diluent $\left(\mathrm{H}_{2} \mathrm{O}\right)$. The result was obtained after $10 \mathrm{~min}$.

\subsubsection{Prognostic Inflammatory and Nutritional Index}

Since the plasma concentrations of so-called nutritional proteins are influenced by inflammatory syndrome, Ingenbleek and Carpentier [10] proposed to 
correct the fluctuations of these proteins by variations in more specific proteins of an inflammatory syndrome such as CRP and orosomucoid. In 1985, they proposed an index, PINI, which combines the measurement of two inflammatory proteins (CRP and orosomucoid) and two nutrition proteins (albumin and prealbumin), according to the following equation:

$$
\mathrm{PINI}=\frac{\mathrm{CRP} \times \text { Orosomucoid }}{\text { Albumin } \times \text { Prealbumin }}
$$

This index makes it possible to classify malnourished patients into five groups:

$>\quad \mathrm{PINI}<1$ : patient not infected, not malnourished

> $\mathrm{PINI}=1$ to 10 : patient at low risk

$>\quad \mathrm{PINI}=11$ to 20 : patient at moderate risk

$>\mathrm{PINI}=21$ to 30 : patient at high risk of complications

$>\quad \mathrm{PINI}>30$ : patient at critical risk

\subsection{Statistical Analysis Methods}

Statistical analysis was performed using GraphPad Prism 5 Demo software, and Student's t-test was used to compare the variances of the means. Relationships between data were assessed using Pearson's chisquared test. A value of $p<0.05$ is considered statistically significant. Data are presented as the mean \pm standard deviation of the mean.

\section{RESULTS}

\subsection{Average Values of the Biological Parameters of the Study Population}

Generally, protein values were within the range of reference values. However, for albumin, students in groups 3 (PDN) and 4 (PDSN) showed a slight increase in mean values compared to group 1 , the control (RSP). These values varied from $41.32 \pm 0.95$ to $42.24 \pm 0.95 \mathrm{~g} / \mathrm{L}$ in group 3 and from $37.07 \pm 1.12$ to $41.51 \pm 1.71 \mathrm{~g} / \mathrm{L}$ in group 4 . On the other hand, in group 1 (control group, RSP), the concentrations varied from $39.79 \pm 0.94$ to $39.55 \pm 0.86 \mathrm{~g} / \mathrm{L}$. This increase was significant in phase 1 (3 months after food consumption), with a p-value $<0.0001$ for group 3 and $p=0.0003$ for group 4 .

In contrast, in group 2 (PDS), there was a nonsignificant decrease $(p>0.05)$ in the mean albumin value $(41.25 \pm 0.98$ to $38.16 \pm 1.17 \mathrm{~g} / \mathrm{L})$ compared to group 1 (RSP). In group 2, the mean prealbumin values decreased without significant difference, ranging from $0.15 \pm 0.04$ to $0.13 \pm 0.04 \mathrm{~g} / \mathrm{L}$, whereas in groups 3 and 4 , the mean prealbumin values remained constant.

The mean CRP value in the different groups decreased from phase 1 for group 1 (2.71 \pm 0.64 to $2.06 \pm 0.26 \mathrm{mg} / \mathrm{L})$ and group $4(2.84 \pm 0.46$ to $2.38 \pm$ $0.36 \mathrm{mg} / \mathrm{L})$ and inphase 2 for groups 2 (3.67 \pm 0.99 to $1.98 \pm 0.32 \mathrm{mg} / \mathrm{L})$ and $3(7.89 \pm 2.39$ to $2.55 \pm 0.32$ $\mathrm{mg} / \mathrm{L})$, compared to group 1 .

Regarding the mean value of orosomucoid, it increased in group $3(0.70 \pm 0.04$ to $0.74 \pm 0.04 \mathrm{~g} / \mathrm{L})$ and group $4(0.67 \pm 0.04$ to $0.74 \pm 0.04 \mathrm{~g} / \mathrm{L})$ without significant difference $(p>0.05)$. On the other hand, adecrease in this parameter was observed in group 2 $(0.73 \pm 0.03$ to $0.64 \pm 0.05 \mathrm{~g} / \mathrm{L})$ without significant difference, compared to group 1.

The mean value of PINI was less than 1 in the whole study. Thus, whatever the group or phase, a progressive decrease in the mean value of PINI was observed: from 0.75 to 0.38 in group 1 , from 0.70 to 0.34 in group 2 , from 0.91 to 0.45 in group 3 , and from 0.83 to 0.39 in group 4 (Table 1).

\subsection{Percentage Reduction in Prognostic Inflammatory and Nutritional Index}

The reduction in PINI was around 0.37 in group 1 (RSP), 0.36 in group 2 (PDS), 0.46 in group 3 (PDN), and 0.44 in group 4 (PDSN). The greatest reduction concerned the pupils of group 3 (Figure 1).

\subsection{Distribution of the Study Population According to PINI Values}

Whatever the group or phase, more than $80 \%$ of this study population were uninfected and not malnourished (PINI <1). Indeed, 6months after the consumption of meals, $90 \%, 95 \%, 86.7 \%$, and $90 \%$ of the population of groups 1 (RSP), 2 (PDS), 3 (PDN), and 4 (PDSN), respectively, were in this situation. However, a low risk of inflammation in $5 \%$ to $20 \%$ of children and a moderate risk of inflammation in $1.7 \%$ of children have been shown. In fact, 6 months after the consumption of meals, $10 \%, 5 \%, 13.3 \%$, and $10 \%$ of the population of groups 1 (RSP), 2 (PDS), 3 (PDN), and 4 (PDSN), respectively, had a low risk of inflammation (Table 2). 
Table 1: Mean Values of Protein Parameters and Prognostic Inflammatory and Nutritional Index of the Study Population

\begin{tabular}{|c|c|c|c|c|c|c|c|c|}
\hline Parameter & Phase & $\begin{array}{l}\text { Group } 1 \\
(n=60)\end{array}$ & $\begin{array}{l}\text { Group } 2 \\
(n=60)\end{array}$ & P-value ${ }^{a}$ & $\begin{array}{l}\text { Group } 3 \\
(n=60)\end{array}$ & P-value ${ }^{b}$ & $\begin{array}{c}\text { Group } 4 \\
(n=60)\end{array}$ & P-value ${ }^{c}$ \\
\hline \multirow{3}{*}{$\begin{array}{l}\text { Albumin } \\
(35-45 \mathrm{~g} / \mathrm{L})\end{array}$} & 0 & $39.79 \pm 0.94$ & $41.25 \pm 0.98$ & 0.2852 & $41.32 \pm 0.95$ & 0.2557 & $37.07 \pm 1.12$ & 0.0654 \\
\hline & 1 & $34.87 \pm 1.33$ & $38.16 \pm 1.17$ & 0.0662 & $41.82 \pm 0.92$ & $<0.0001$ & $40.59 \pm 0.73$ & 0.0003 \\
\hline & 2 & $39.55 \pm 0.86$ & $38.16 \pm 1.37$ & 0.3939 & $42.24 \pm 0.76$ & 0.0213 & $41.51 \pm 0.72$ & 0.0853 \\
\hline \multirow{3}{*}{$\begin{array}{l}\text { Prealbumin } \\
(0.20-0.40 \mathrm{~g} / \mathrm{L})\end{array}$} & 0 & $0.14 \pm 0.03$ & $0.15 \pm 0.04$ & 0.1258 & $0.14 \pm 0.04$ & 0.9863 & $0.13 \pm 0.03$ & 0.1804 \\
\hline & 1 & $0.15 \pm 0.03$ & $0.13 \pm 0.04$ & 0.0020 & $0.14 \pm 0.04$ & 0.1290 & $0.14 \pm 0.04$ & 0.0936 \\
\hline & 2 & $0.14 \pm 0.04$ & $0.13 \pm 0.04$ & 0.2100 & $0.14 \pm 0.08$ & 0.8060 & $0.13 \pm 0.04$ & 0.2039 \\
\hline \multirow{3}{*}{$\begin{array}{l}\text { C-reactive protein } \\
\qquad(<10 \mathrm{mg} / \mathrm{L})\end{array}$} & 0 & $3.65 \pm 0.69$ & $3.19 \pm 0.62$ & 0.6180 & $4.29 \pm 0.90$ & 0.5740 & $7.89 \pm 2.39$ & 0.6972 \\
\hline & 1 & $2.71 \pm 0.64$ & $3.67 \pm 0.99$ & 0.4173 & $7.89 \pm 2.39$ & 0.4596 & $2.84 \pm 0.46$ & 0.8645 \\
\hline & 2 & $2.06 \pm 0.26$ & $1.98 \pm 0.32$ & 0.8475 & $2.55 \pm 0.32$ & 0.2394 & $2.38 \pm 0.36$ & 0.4799 \\
\hline \multirow{3}{*}{$\begin{array}{c}\text { Orosomucoid } \\
\text { (B: } 0.52-1.25 \mathrm{~g} / \mathrm{L}) \\
\text { (G: } 0.48-1.29 \mathrm{~g} / \mathrm{L})\end{array}$} & 0 & $0.80 \pm 0.03$ & $0.73 \pm 0.03$ & 0.1358 & $0.70 \pm 0.04$ & 0.0516 & $0.67 \pm 0.04$ & 0.0142 \\
\hline & 1 & $0.81 \pm 0.03$ & $0.71 \pm 0.05$ & 0.0249 & $0.73 \pm 0.03$ & 0.0184 & $0.71 \pm 0.04$ & 0.0066 \\
\hline & 2 & $0.80 \pm 0.03$ & $0.64 \pm 0.05$ & 0.0061 & $0.74 \pm 0.04$ & 0.2481 & $0.74 \pm 0.04$ & 0.2245 \\
\hline \multirow{3}{*}{ PINI } & 0 & $0.75 \pm 0.17$ & $0.70 \pm 0.23$ & 0.8527 & $0.91 \pm 0.22$ & 0.5854 & $0.83 \pm 0.20$ & 0.7675 \\
\hline & 1 & $0.68 \pm 0.25$ & $0.51 \pm 0.10$ & 0.5501 & $0.39 \pm 0.06$ & 0.2698 & $0.42 \pm 0.08$ & 0.3368 \\
\hline & 2 & $0.38 \pm 0.07$ & $0.34 \pm 0.08$ & 0.6707 & $0.45 \pm 0.08$ & 0.4589 & $0.39 \pm 0.07$ & 0.8967 \\
\hline
\end{tabular}

a: group 1 vs. group 2; b: group 1 vs. group 3; c: group 1 vs. group 4 . The difference is significant for $p<0.05$ (Student's t test).

B:Boy; G: Girl.

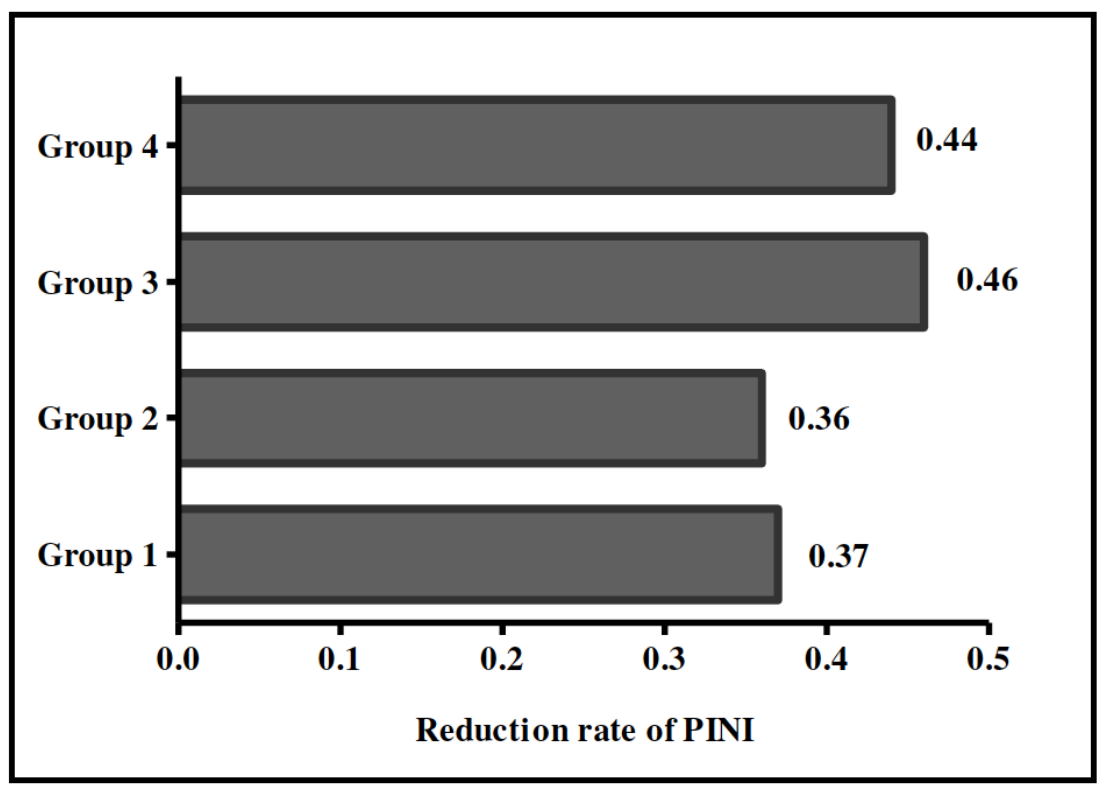

Figure 1: Variation of mean PINI value during the study.

\section{DISCUSSION}

PINI groups together two inflammatory parameters (CRP and orosomucoid) and two nutritional parameters (albumin and prealbumin) [10]. It is determined in order to simultaneously assess the inflammatory and nutritional status. This index is used to classify patients as uninfected and not malnourished or at low, moderate, high, or critical risk of complications and inflammation [19].

In this study, a gradual decrease in the mean values of PINI was observed in all groups of students over the period in which they consumed the different dishes, with reduction rates between 0.36 and 0.47 . This decrease in PINI values agrees with the results of Vehe 
Table 2: Distribution of the Study Population According to the Inflammatory Process

\begin{tabular}{|c|c|c|c|c|c|c|}
\hline Group & Phase & PINI < 1 & $1 \leq \mathrm{PINI}<10$ & $11 \leq \mathrm{PINI}<20$ & $21 \leq \mathrm{PINI}<30$ & PINI $>30$ \\
\hline \multirow{3}{*}{1} & 0 & $49(81.7 \%)$ & $11(18.3 \%)$ & $0(0 \%)$ & $0(0 \%)$ & $0(0 \%)$ \\
\hline & 1 & $53(88.3 \%)$ & $6(10 \%)$ & $1(1.7 \%)$ & $0(0 \%)$ & $0(0 \%)$ \\
\hline & 2 & $54(90 \%)$ & $6(10 \%)$ & $0(0 \%)$ & $0(0 \%)$ & $0(0 \%)$ \\
\hline \multirow{3}{*}{2} & 0 & $51(85 \%)$ & $8(13.3 \%)$ & $1(1.7 \%)$ & $0(0 \%)$ & $0(0 \%)$ \\
\hline & 1 & $51(85 \%)$ & $9(15 \%)$ & $0(0 \%)$ & $0(0 \%)$ & $0(0 \%)$ \\
\hline & 2 & $57(95 \%)$ & $3(5 \%)$ & $0(0 \%)$ & $0(0 \%)$ & $0(0 \%)$ \\
\hline \multirow{3}{*}{3} & 0 & $48(80 \%)$ & $12(20 \%)$ & $0(0 \%)$ & $0(0 \%)$ & $0(0 \%)$ \\
\hline & 1 & $52(86.7 \%)$ & $8(13.3 \%)$ & $0(0 \%)$ & $0(0 \%)$ & $0(0 \%)$ \\
\hline & 2 & $52(86.7 \%)$ & $8(13.3 \%)$ & $0(0 \%)$ & $0(0 \%)$ & $0(0 \%)$ \\
\hline \multirow{3}{*}{4} & 0 & $48(80 \%)$ & $12(20 \%)$ & $0(0 \%)$ & $0(0 \%)$ & $0(0 \%)$ \\
\hline & 1 & $54(90 \%)$ & $6(10 \%)$ & $0(0 \%)$ & $0(0 \%)$ & $0(0 \%)$ \\
\hline & 2 & $54(90 \%)$ & $6(10 \%)$ & $0(0 \%)$ & $0(0 \%)$ & $0(0 \%)$ \\
\hline
\end{tabular}

et al. [20], who observed a significant decrease in PINI values from the start to the finish of their study. According to them, these low values of PINI (below 1) would be due to a decrease in the concentration of CRP, a slight increase in the concentrations of prealbumin and albumin, and the non-variation of orosomucoid concentration, as also observed in this present study during the different phases. Indeed, during malnutrition, a decrease in nutritional proteins is observed in favor of inflammatory proteins [9]. The slight increase in albumin observed in this study would be due to the consumption of dishes made from sweet potato (I. batatas), known for its high protein content $[6,21,22]$, especially in groups 3 (PDN) and 4 (PDSN). The same is true for soybean (G. max) [7] and cowpea (V. unguiculata), which represent an important source of protein to some populations $[8,23]$. This result clearly shows the positive impact of dietary diversification on PINI, particularly CRP, thus showing an absence of inflammatory syndrome in the entire study population. Indeed, the nutritional composition of foods is involved in the fight against malnutrition, the biological signs of which are disruption of nutritional and inflammatory proteins. In addition, during malnutrition, the body is faced with two important requirements.

On the one hand, the body must have sufficient resources (proteins) to fight against the causes of malnutrition; on the other, it is necessary to repair the consequences of malnutrition by reconstituting its stock of proteins in order to support the functioning of other organs [24]. However, a low risk of inflammation in 5\% to $20 \%$ of children and a moderate risk of inflammation in $1.7 \%$ of children have been shown. These results can be explained by the infectious tropical environment in which these children live [25]. Indeed, several studies have shown that tropical pathologies, particularly parasitoses (intestinal parasites, Plasmodium falciparum, and others), tend to constantly stimulate the immune system [26].

\section{CONCLUSION}

In this study, a progressive decrease in the mean PINI value was observed in all groups of students during the period they consumed the different dishes. This situation concerned more than $80 \%$ of the children, whatever the group or phase, and would be due to a decrease in CRP concentration, a slight increase in the concentrations of prealbumin and albumin, and the non-variation of orosomucoid concentration. The greatest reduction concerned pupils who consumed the meal based on sweet potato porridge enriched with white cowpea. Dietary diversification, particularly through the intake of protein provided by meals based on sweet potato and white cowpea, has a positive impact on PINI and hence on nutritional status.

\section{ETHICAL APPROVAL}

This study was authorized by the national research ethics committee (N/Ref: 009//MSHP/CNER-Kp). In addition, the authorities of each village and the school headteachers were contacted and informed before the start of the study in their localities. Their approval was required before the start of the study. 


\section{CONSENT}

A standardized questionnaire survey focusing in particular on food and hygiene habits and medical history was conducted for each child. Informed, written, and signed consent was obtained from each parent or guardian of the participating students after discussion of the purpose and benefits of the study and from each manager of each institution involved in the study. Participants were informed of their volunteering and of the right to leave the survey at any time. The confidentiality of the information of study participants was also ensured. Only anonymized data were used for statistical analysis.

\section{CONFLICTS OF INTEREST}

The authors declare that they have no conflict of interest.

\section{SUPPLEMENTAL MATERIALS}

The supplemental materials can be downloaded from the journal website along with the article.

\section{REFERENCES}

[1] N'go P, Azzaoui F, Ahami A, Aboussaleh Y, Lachheb A, Hamrani A. Socioeconomic determinants, environmental and nutritional issues of school failure: cases children living in the cocoa zone of Soubré (Côte of Ivory) (in French). Antropo 2012; 28: 63-70. http://www.didac.ehu.es/antropo/28/288/Ngo.pdf

[2] Bleyere MN, Kokore BA, Konan AB, Yapo PA. Prevalence of child malnutrition through their anthropometric indices in school canteens of Abidjan (Côte d'ivoire). Pakistan J Nutr 2013; 12(1): 60-70. https://doi.org/10.3923/pjn.2013.60.70

[3] Agbo AE, Mahyao A, Konan AD, Coulibaly L, Kouassi A, Kehlenbeck $\mathrm{K}$, et al. Production, consumption, and nutrition survey in a cocoa farming area in the Nawa region. Report. ICRAF, Abidjan 2014; p. 137.

[4] De Oliveira Otto MC, Anderson CAM, Dearborn JL, Ferranti EP, Mozaffarian D, Rao G, et al. Dietary diversity: Implications for obesity prevention in adult populations: A Science Advisory from the American Heart Association. Circulation 2018; 138(11): e160-e168. https://doi.org/10.1161/CIR.0000000000000595

[5] WHO and UNICEF. Global strategy for infant and young child feeding. Fifty-fourth world Health Assembly 2003. https://apps.who.int/iris/bitstream /handle/10665/42590/9241562218.pdf

[6] Alam MK, Sams S, Rana ZH, Akhtaruzzaman M, Islam SN. Minerals, vitamin $\mathrm{C}$, and effect of thermal processing on carotenoids composition in nine varieties orange-fleshed sweet potato (Ipomoea batatas L.). J Food Compos Anal 2020; 92: 103582.

https://doi.org/10.1016/j.jfca.2020.103582

[7] Lokuruka M. Soybean nutritional properties: The good and the bad about soy foods consumption - A review. African $J$ Food, Agric Nutr Dev 2010; 10(4): 2439-2459.

https://doi.org/10.4314/ajfand.v10i4.55335
Frota KDMG, Lopes LAR, Silva ICV, Arêas JAG. Nutritional quality of the protein of Vigna unguiculata L. Walp and its protein isolate. Rev Cienc Agron 2017; 48(5): 792-98. https://doi.org/10.5935/1806-6690.20170092

[9] M'Boh MG, Ahiboh HT, Yapo A, Bla BK, Djaman JA, Yapi $\mathrm{FH}$. The effect of falciparum malaria infection on the quantity of trace elements (iron, copper, zinc) in the blood in children of Côte d'Ivoire. Agric Biol J N Am 2010; 1(4): 565-70.

[10] Ingenbleek Y, Carpentier YA. A prognostic inflammatory and nutritional index scoring critically ill patients. Int $\mathrm{J}$ Vitam Nutr Res 1985; 55(1): 91-101.

[11] Keller U. Nutritional Laboratory Markers in Malnutrition. J Clin Med 2019; 8(6): 775 https://doi.org/10.3390/jcm8060775

[12] Idohou-Dossou N, Wade S, Guiro AT, Sarr CS, Diaham B, Cissé $\mathrm{D}$, et al. Nutritional status of preschool Senegalese children: long-term effects of early severe malnutrition. $\mathrm{Br} \mathrm{J}$ Nutr 2003; 90(6): 1123-32. https://doi.org/10.1079/BJN2003990

[13] Price CP, Trull AK, Berry D, Gorman EG. Development and validation of a particle-enhanced turbidimetric immunoassay for C-reactive protein. J Immunol Methods 1987; 99(2): 20511. https://doi.org/10.1016/0022-1759(87)90129-3

[14] Eda S, Kaufmann J, Roos W, Pohl S. Development of a new microparticle-enhanced turbidimetric assay for C- reactive protein with superior features in analytical sensitivity and dynamic range. J Clin Lab Anal 1998; 12(3): 137-44. https://doi.org/10.1002/(SICl)10982825(1998)12:3<137::AID-JCLA2>3.0.CO;2-6

[15] Colombo S, Buclin T, Décosterd LA, Telenti A, Furrer H, Lee $\mathrm{BL}$, et al. Orosomucoid ( $\alpha 1$-acid glycoprotein) plasma concentration and genetic variants: Effects on human immunodeficiency virus protease inhibitor clearance and cellular accumulation. Clin Pharmacol Ther 2006; 80(4): 30718.

https://doi.org/10.1016/j.clpt.2006.06.006

[16] Doumas BT, Ard Watson W, Biggs HG. Albumin standards and the measurement of serum albumin with bromocresol green. Clin Chim Acta 1971; 31(1): 87-96. https://doi.org/10.1016/0009-8981(71)90365-2

[17] Spencer K, Price CP. Kinetic immunoturbidimetry: The estimation of albumin. Clin Chim Acta 1979; 95(2): 263-76. https://doi.org/10.1016/0009-8981(79)90368-1

[18] Hutchinson DR, Smith MG, Parke DV. Prealbumin as an index of liver function after acute paracetamol poisoning. Lancet 1980; 316(8186): 121-3. https://doi.org/10.1016/S0140-6736(80)90006-9

[19] Calder PC, Albers R, Antoine JM, Blum S, Bourdet-Sicard R, Ferns GA, et al. Inflammatory disease processes and interactions with nutrition. Br J Nutr 2009; 101(S1): 1-45 https://doi.org/10.1017/S0007114509377867

[20] Vehe KL, Brown RO, Kuhl DA, Boucher BA, Lutherou RW Kudsk KA. The prognostic inflammatory and nutritional index in traumatized patients receiving enteral nutrition support. $J$ Am Coll Nutr 1991; 10(4): 355-63. https://doi.org/10.1080/07315724.1991.10718163

[21] Sun H, Mu T, Xi L, Zhang M, Chen J. Sweet potato (Ipomoea batatas L.) leaves as nutritional and functional foods. Food Chem 2014; 156: 380-89. https://doi.org/10.1016/j.foodchem.2014.01.079

[22] Aywa AK, Nawiri MP, Nyambaka HN. Nutrient variation in colored varieties of Ipomea batatas grown in Vihiga county, Western Kenya. Int Food Res J 2013; 20(2): 819-25 http://www.ifrj.upm.edu.my/20\%20(02)\%202013/44\%20IFRJ \%2020\%20(02)\%202013\%20Mildred\%20(174).pdf 
[23] Kalpanadevi V, Mohan VR. Effect of processing on antinutrients and in vitro protein digestibility of the underutilized legume, Vigna unguiculata (L.) Walp subsp. unguiculata. LWT - Food Sci Technol 2013; 51(2): 455-61. https://doi.org/10.1016/j.Iwt.2012.09.030

[24] Youan GP, Kouakou YKF, Bamba A, Koffi AE, Yapi HF. Evolution of the pronostic inflammatory and nutritional index (PINI) of the malnourished children of 6-59 months during supplementation with Soya and Spirulina in Côte d'Ivoire. Int J Biochem Res Rev 2017; 17(1): 1-8. https://doi.org/10.9734/IJBCRR/2017/32951
[25] Haraga J, Nakamura K, Omichi C, Nishida T, Haruma T, Kusumoto $\mathrm{T}$, et al. Pretreatment prognostic nutritional index is a significant predictor of prognosis in patients with cervical cancer treated with concurrent chemoradiotherapy. Mol Clin Oncol 2016; 5(5): 567-74.

https://doi.org/10.3892/mco.2016.1028

[26] Kamradt T, Göggel R, Erb KJ. Induction, exacerbation, and inhibition of allergic and autoimmune diseases by infection. Trends Immunol 2005; 26(5): 260-67.

https://doi.org/10.1016/j.it.2005.03.009

Received on 26-06-2021

Accepted on 29-10-2021

Published on 31-12-2021

https://doi.org/10.6000/1929-4247.2021.10.04.3

(c) 2021 Allico et al.; Licensee Lifescience Global.

This is an open access article licensed under the terms of the Creative Commons Attribution License (http://creativecommons.org/licenses/by/4.0/) which permits unrestricted use, distribution and reproduction in any medium, provided the work is properly cited. 